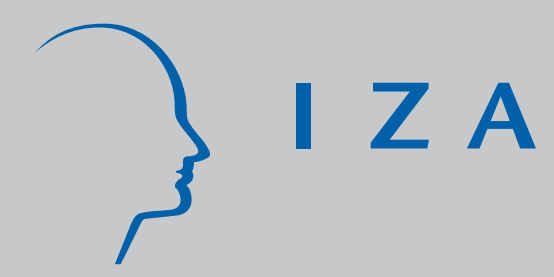

IZA DP No. 105

Ownership or Performance: What Determines Board of Directors' Turnover in Italy?

Giorgio Brunello

Clara Graziano

Bruno Parigi

J anuary 2000 


\title{
Ownership or Performance: What Determines Board of Directors' Turnover in Italy?
}

\author{
Giorgio Brunello \\ Clara Graziano \\ University of Udine, Italy \\ Bruno Parigi \\ University of Padua, Italy
Discussion Paper No. 105 January 2000 \\ IZA \\ P.O. Box 7240 \\ D-53072 Bonn \\ Germany \\ Tel.: +49-228-3894-0 \\ Fax: +49-228-3894-210 \\ Email: iza@iza.org
}

University of Padua, Italy and IZA, Bonn

This Discussion Paper is issued within the framework of IZA's research area General Labor Economics. Any opinions expressed here are those of the author(s) and not those of the institute. Research disseminated by IZA may include views on policy, but the institute itself takes no institutional policy positions.

The Institute for the Study of Labor (IZA) in Bonn is a local and virtual international research center and a place of communication between science, politics and business. IZA is an independent, nonprofit limited liability company (Gesellschaft mit beschränkter Haftung) supported by the Deutsche Post AG. The center is associated with the University of Bonn and offers a stimulating research environment through its research networks, research support, and visitors and doctoral programs. IZA engages in (i) original and internationally competitive research in all fields of labor economics, (ii) development of policy concepts, and (iii) dissemination of research results and concepts to the interested public. The current research program deals with (1) mobility and flexibility of labor markets, (2) internationalization of labor markets and European integration, (3) the welfare state and labor markets, (4) labor markets in transition, (5) the future of work, (6) project evaluation and (7) general labor economics.

IZA Discussion Papers often represent preliminary work and are circulated to encourage discussion. Citation of such a paper should account for its provisional character. 


\section{ABSTRACT \\ Ownership or Performance: What Determines Board of Directors' Turnover in Italy?}

This paper studies the turnover of board of directors members in a sample of 72 companies listed on the Milan Stock Exchange during the period 1988-1996. We investigate whether board members change more frequently when company performance is poor, as the literature suggests, and whether and how the ownership structure of Italian companies affects these relationships. We find that there is a statistically significant and negative relationship between firm performance and CEO turnover and that this relationship depends on the ownership structure of firms. Turnover is lower in family controlled firms and higher in firms that experienced a change in the controlling shareholder. The latter firms also have a stronger turnover-performance relationship. We find evidence supporting the hypothesis that changes in control are an extreme form of turnover. We also find evidence of a monitoring role of the second largest shareholder. Also the turnover of top executives exhibits a negative relationship with performance. Board turnover instead is unrelated to performance but is related to the firm's ownership structure. Overall our findings suggest that the characteristics of the Italian economy deeply affect the turnover of directors and have implications that go beyond the specific case study.

JEL Classification: G34, J63

Keywords: Board of directors, corporate governance, financial agency

Giorgio Brunello

Department of Economics

University of Padua

Via del Santo 33

35123 Padua

Italy

Tel: 390418274223

Fax: 390418274221

Email: brunello@decon.unipd.it

\footnotetext{
We would like to thank Marcello Bianchi, Loretta Mester, Loriana Pelizzon and audiences at the Universities of Bologna, Roma-Tor Vergata, Cattolica-Milan, Siena, Bocconi-IGIER, at the conference on Corporate Governance, Contracts, and Managerial Incentives at Humboldt University in Berlin, at the Third CONSOB Seminar on Italian Financial Services, the EAIRE meeting in Turin, and the British Accounting Association Conference on Corporate Governance at Sheffield University for helpful suggestions. Geraldine Ludbrook, Franco Mariuzzo, Nicola Menis and Lorenzo Rocco provided valuable research assistance. Financial support from the National Research Council (C.N.R.) Grant N.96.01407.CT10 and from the Italian Ministry of University is gratefully acknowledged. The usual disclaimers apply.
} 


\section{Introduction}

Corporate governance issues have recently received much attention in Italy both from policy-makers and the public because of recent privatizations, a sweeping reform of corporate law $^{1}$, and the integration of European capital markets. Academic studies on the working of various aspects of Italian corporate governance have begun to appear. ${ }^{2}$ However, little academic research has been devoted so far to studying the behavior of boards of directors, an institution, which plays a key role in the internal mechanism of corporate governance in Italy, where external mechanisms of corporate governance are weak. Italian capitalism is often characterized by the importance of family control through pyramidal groups, the relative absence of hostile takeovers, an underdeveloped capital market and the lack of a main-bank relationship. Because these (and other) features make the Italian system quite different both from the Anglo-Saxon model and the German and Japanese models, investigating board of directors turnover in such an environment has implications that go beyond the specific case study, as we shall see in Section 3.

This paper analyzes the turnover of members of corporate boards of directors using a sample of companies listed on the Italian Stock Exchanges over the 9-year period 19881996. Our aim is to investigate whether board members change more frequently when company performance is poor, as the literature suggests, and whether and how the firm's ownership structure and the specificities of Italian capitalism affect the turnoverperformance relationship. We use three different definitions of directors: Definition A, all directors in the board; Definition B, the top executives, i.e. President, Vice-President, CEO (Amministratore Delegato) and General Manager (Direttore Generale); and Definition C,

\footnotetext{
${ }_{2}^{1}$ A major reform affecting corporate governance (known as "Legge Draghi") became law in July 1998.

2 Among the first studies of corporate governance in Italy Barca (1994) and Caprio et al. (1994) look at the ownership structure and Zingales (1994) studies voting rights. Brunello, Graziano and Parigi (1999) look at the implications of the Italian system of corporate governance for managerial incentives and pay in a sample of Italian firms. Bianco and Casavola (1999) study the links between ownership concentration and firm performance in Italian companies.
} 
the CEOs. ${ }^{3}$ We consider turnover for each definition of directors.

To preview our main findings we find that there is a statistically significant and negative relationship between firm performance and CEO turnover and that this relationship depends on the ownership characteristics of firms. CEO turnover is lower in family-controlled firms and higher in firms that experienced a change in the controlling shareholder. The turnover performance relationship is higher in firms that changed control in the sample period and lower in state-owned firms. Furthermore, we find evidence supporting the hypothesis that changes in control are an extreme form of turnover often related to poor firm performance. We also find evidence of a monitoring role of the second largest shareholder. Finally, also the turnover of top executives exhibits a negative relationship with firm performance. Board turnover, instead, is unrelated to performance but is related to the firm's ownership structure.

The rest of the paper is organized as follows. Section 2 reviews the literature on ownership structure and board turnover that is relevant to this paper. Section 3 describes the main features of boards of directors in Italy and their implications for board of directors turnover. Section 4 describes the data. Section 5 provides summary statistics about both the directors and the firms in the sample. Section 6 is devoted to the discussion of the results of our empirical analysis. Section 7 summarizes our findings.

\section{Related Literature}

Two related strands of literature are relevant to this paper: the literature on the relationship between firm performance and board of directors turnover, and the literature on the relationship between ownership structure and top management incentives.

\section{Board Turnover}

${ }^{3}$ Large companies may have more than one CEO. 
Much has been published on the relationship between firm performance and top management turnover in the U.S. (see, among others, Coughlan and Schmidt, 1985, Warner, Watts and Wruck, 1988, Denis et al., 1997, and the surveys by Kose and Senbet, 1998 and Mayer, 1998). These studies are largely based on the first-generation agency theory of the firm, where managers are agents of dispersed shareholders. Three of the results obtained in this literature are relevant to the present paper. First, top executive turnover is negatively related both to stock performance and to accounting-based firm performance measures (earnings, sales etc.). Second, this relationship is stronger when the board is dominated by outside directors (Weisbach, 1988) or in firms with a block shareholder (Denis et al., 1997). Third, management ownership has an ambiguous effect on board behavior. On the one hand, boards with significant managerial ownership are more likely to behave in the interest of shareholders (Morck et al., 1988, Hermalin and Weisbach, 1988). On the other hand, executive ownership may also cause managerial entrenchment, thus making it more difficult to remove an underperforming manager. Indeed, Denis et al. (1997) find that, after controlling for poor stock performance, the probability of top management turnover is negatively related to their equity ownership (see also Rosenstein and Wyatt, 1997).

A negative relationship between top executive turnover and firm performance has also been found in Japan and Germany, two countries whose corporate governance models are generally described as relationship-oriented in contrast to the market-oriented U.S. system. Poor stock performance as well as poor sales and earnings increase the likelihood of executive turnover both in Japan and in Germany (Kaplan 1994a and 1994b, Kang and Shivdasani, 1995). In his study of Germany, Kaplan also tests whether the turnover-performance relationship is a function of the concentration of shares and of voting rights. If large shareholders play an important monitoring role, the turnoverperformance sensitivity should be stronger in firms with a controlling shareholder or with 
bank control. He finds that the relationship does not vary with ownership concentration or with bank voting power. A possible explanation of this result is that all the companies in the sample have similar ownership concentration and therefore similar monitoring.

A negative relationship between performance and turnover is also found in other Continental European countries, including Spain (Gispert, 1998), Denmark (Lausten, 1998) and Belgium (Renneboog, 1996). Gispert (1998) uses a sample of large Spanish listed companies and finds that there is a statistically significant and negative relationship between board turnover and firm performance. This negative relationship is weakened by ownership concentration, while the nature of the largest shareholder (financial companies, other firms, individuals etc.) does not influence the probability of turnover. Lausten (1998) focuses on CEO turnover in a sample of medium and large Danish firms. Her main result is that there is an inverse relationship between CEO turnover and firm performance measured by pre-tax accounting profit relative to sales, and that the probability of turnover is lower when the firm is family controlled. Finally, Renneboog (1996) documents that poor performance of Belgian listed companies increases the probability of turnover of executive directors, of members of the management committee and of the CEO. In his study, increased ownership concentration leads, ceteris paribus, to higher board turnover. To summarize, a variety of studies show that countries with different corporate governance systems exhibit a negative relationship between firm performance and CEO turnover.

The relationship between ownership structure and turnover is instead much less understood and qualitatively different among countries. Evidence on the relationship between board changes and ownership changes in the US is provided by Denis and Sarin (1999) over the 10-year period 1983-1992. Their main findings are that substantial changes in equity ownership and board structure are significantly correlated with one another and tend to persist over time. Moreover, corporate control threats and prior stock 
price performance are the main factors affecting changes in ownership and board composition.

\section{Ownership Structure}

A recent and growing body of research investigates the agency problems that arise from the different patterns of separation of ownership and control. On the theoretical side, several studies address the issue of the different roles of controlling and non-controlling shareholders and stress the monitoring role of large shareholders (e.g. Shleifer and Vishny, 1986). However, ownership concentration in the hands of large shareholders may have costs because of lower market liquidity (Bolton and Von Thadden, 1998), because large shareholders may exert excess monitoring (Pagano and Röell, 1998), and because monitoring by large shareholders comes at the cost of managerial discretion (Burkart, Gromb, and Panunzi, 1997). On the empirical side several studies have shown that ownership patterns around the world very often differ from the widely-held corporation controlled by unaccountable managers. In particular the cross-country studies of La Porta et al. $(1997,1999)$ point out that ownership of large companies in rich economies is typically concentrated; that control is often exercised through pyramidal groups with a holding company at the top controlling one or more subsidiaries; that families are often the controlling shareholders; and that the controlling shareholders are often actively involved in company management and sit on the board of directors. ${ }^{4}$

Family control through pyramidal groups appears to be an intermediate form between closely-held family business and public companies. On the one hand, the controlling shareholders generally take an active interest in company matters. This pattern is hardly the exception around the world where, according to La Porta et al. (1999),

\footnotetext{
${ }^{4}$ These features are particularly important in Italy where hierarchical group control accounts for over $57 \%$ (32.6\%) of manufacturing companies with more (less) than 200 employees (Bianco, Gola, Signorini, 1996). For a description of pyramidal groups in Italy see Brioschi et al. (1990) and Barca (1996).
} 
it is often the case that families controlling the largest firms also participate in management. On the other hand, the strong leverage effect of the pyramid gives the shares of the controlling shareholders more votes than those of other shareholders (Shleifer and Vishny, 1996, Barca, 1996, Nicodano, 1998), thus guaranteeing control with a small fraction of the voting shares, as in public companies (La Porta et al., 1999). In this context, separation of ownership and control generates a two-level agency problem: between controlling shareholders and management, and between minority shareholders and controlling shareholders. The first agency problem is mitigated both by promotion, firing and incentive pay for managers, and by the active involvement of the controlling shareholders, who closely monitor outside managers. The main agency problem, however, arises between non-controlling shareholders and controlling shareholders who often have control rights in excess of their cash flow rights (La Porta et al., 1999). To discipline controlling shareholders adequate legal protection of minority shareholders and a well-functioning market for corporate control are required.

\section{Boards of directors in Italy and implications for board turnover}

\section{Boards of Directors}

A number of factors indicate that the independence of boards of directors is quite limited in Italy. First, although the members of the board of directors have fiduciary duties with respect to all shareholders ${ }^{5}$, they mainly represent the interests of the controlling shareholders, minority shareholders being typically not well represented. A survey conducted in 1994 (Crisci and Tarizzo, 1995) on the Boards of Directors of 500 Italian companies provides a clear picture. To the question "Who do you represent in the board?" $83 \%$ of the directors answered "the controlling shareholders" and only $12 \%$ "the 
minority shareholders". Second, in 1995 in all the op twenty Italian firms by stock market capitalization a member of the controlling family is on the board as Chairman, CEO, Honorary Chairman, or Vice-Chairman of the firm controlled by that family (La Porta et al., 1999). Third, outside directors are rare. Crisci and Tarizzo (1995) report that in most instances the new director had previous strong ties with the firm: in $64 \%$ of the cases directors were chosen among former managers or consultants of the firm, in $26 \%$ of the cases among either shareholders or their relatives, and in only $6 \%$ of the cases the director had no previous relationship with the firm. The same survey reports that the choice of a new director is based more on personal contacts than on the search for the best candidate. Finally, the main task of the directors (more than $70 \%$ of them are executives) is strategic planning and its implementation, while independent monitoring of executives is regarded as a marginal task (Crisci and Tarizzo, 1995). In addition independent monitoring is exerted by the Internal Auditing Committee, which is appointed by the controlling shareholders and has limited power (Barca, 1996).

Board members are appointed by the shareholders for a three-year, generally renewable term with no time limit. Typically there is no mandatory retirement age. The president of the board is elected either by the board or by the shareholders.

\section{Testable implications for board turnover}

The above features of the Italian system of corporate governance have several implications for board turnover that go beyond the specific case study. Our first hypothesis is that in family controlled firms both turnover and turnover-performance sensitivity are lower than in other firms, because managerial ownership shields directors from the threat of removal for poor performance (Hypothesis 1). It is interesting to

\footnotetext{
${ }^{5}$ Directors' fiduciary responsibility to shareholders is explicitly stated in the law, art. 2392 and 1710 of Italian
} 
contrast our hypothesis with Kaplan's (1994b) according to whom, everything else being equal, higher ownership concentration leads to closer monitoring and to higher turnoverperformance sensitivity. The difference arises because his focus is mainly on public companies while the companies in our sample are mainly in family-controlled pyramidal groups.

Second, an additional link between turnover and performance is provided by ownership change. When directors (chiefly top executives and CEOs) are controlling shareholders, in order to remove them control must change as well. We argue that control change is an extreme instance of turnover often related to poor firm performance. The testable implication is that firms that have experienced control changes should exhibit a higher turnover-performance sensitivity; moreover, control change should be more frequent after poor performance (Hypothesis 2).

Third, although there is no general relationship between ownership structure and turnover, as discussed in Section 2, we would expect that, in the absence of control change, the higher the share of the largest shareholder the higher the entrenchment of the directors representing him/her, and hence the lower turnover (Hypothesis 3). Large noncontrolling shareholders may perform an active monitoring role on the actions of the controlling shareholders. The larger the share of the second shareholder, the stronger the incentive to monitor. Thus, we expect higher turnover-performance sensitivity in firms with a large second shareholder (Hypothesis 4). Furthermore, in companies where no shareholder has the absolute majority of votes, the main shareholders are often linked by a syndicate. ${ }^{6}$ Since the board of directors reflects the ownership structure of the firm and its changes, we expect that firms with a syndicate have lower turnover (Hypothesis 5).

\footnotetext{
Civil Code (c.c.).

${ }^{6}$ A shareholders syndicate is a legally binding agreement between two or more shareholders aimed at exercising some of their rights in a predetermined fashion (Art. n.10, Law 18/2/1992, n.149). The most common types of shareholders syndicate are voting trusts, consultation agreements, and agreements limiting the transfers of blocks of shares.
} 
Finally, state-controlled companies may have objectives that differ from valuemaximization. Hence, we expect a weaker relationship between turnover and performance in these companies (Hypothesis 6).

\section{The Data}

Sources: The identity of members of the boards of directors and the measures of accounting-based performance of listed firms are from Calepino dell'Azionista (19871997), an annual publication on Italian listed companies. To eliminate discrepancies, information on board members is cross-checked with information from another stockexchange yearbook, Taccuino dell'Azionista (1987-1997), and from company filings with CONSOB ${ }^{7}$. The data on the ownership structure of firms are both from Taccuino dell' Azionista (1987-1997) and from company filings with CONSOB. Data on shareholders syndicates and on the percentage of shares in each syndicate are from company filings with CONSOB and from Taccuino dell'Azionista (1987-1997). Our data on stock prices and dividends are from the financial newspaper Sole 24 Ore (1987-1998), while data on the changes of nominal capital (e.g. stock splits, free distributions of stocks, rights issues, etc.) are from Taccuino dell'Azionista (1987-1997) and R\&S (1994).

Firm Sample: We consider all firms listed in the Italian Stock Exchanges over the period 1988-1996, excluding banks, insurance companies and financial holding companies. ${ }^{8}$ We also eliminate firms that have been listed for only part of the period and ignore new entries during the period. Hence, our sample includes only "survivors", which can be observed for a relatively long period of time. The endogenous selection of survivors in the sample have empirical consequences that are discussed later in the paper. This gives us a sample of

\footnotetext{
${ }^{7}$ CONSOB (Commissione Nazionale per le Società e la Borsa) is the Italian equivalent of the SEC in the US.

8 Banks, insurance companies and financial holding companies are excluded because, for accounting reasons, before 1993 their performance measures are not easily comparable with those of the other
} 
72 firms, about one third of all listed firms in Italy (the number of listed firms varies between 228 in 1988 and 217 in 1996), including both private and state-owned firms.

Turnover Measures: We use the data on the turnover behavior of individual directors to construct measures of turnover at the firm level, as is done in the literature. Unfortunately, published sources do not allow us to identify the causes of turnover, e.g. forced resignation, voluntary quits, death, illness, retirement, etc. Furthermore, we have no information on whether the company charter specifies a mandatory retirement age.

Turnover is defined as the exit rate from the board between year $t$ and $t+1$. Based on this definition, turnover $\mathrm{A}$ refers to definition $\mathrm{A}$ and is the percentage of directors of a given board that left the office in the reference period; turnover B refers to definition B and is the percentage of top executives directors of a given board that left the office during the same interval. Finally, turnover $C$ refers to definition $C$ and is the percentage of CEOs of a given board that left the office.

Another feature of our data is that our main source (Calepino dell'Azionista) reports information on board members only at the time of the survey (June 30 of each year). Therefore, we have no information on spells on the board that start after the survey in year $t$ and end before the survey in year $t+1$. While this feature leads to a potential underestimate of turnover, cases of directors resigning, or being fired, after only a few months in the job are rare in Italy.

Information on Directors: For each director we have information about his/her gender, the number of years on the board and the total number of directorships held. Information on individual age is also available for most directors in the sample. Based on this information, we have constructed the following company level variables: the average age of board 
directors for each turnover measure $(A G E)$; average number of years spent on the board of a given company by its directors (TENURE); and the average number of positions held in other boards by the directors of a firm (NUMBER OF DIRECTORSHIPS). For each board we have also constructed the variables BOARD SIZE, NUMBER OF TOP EXECUTIVES, NUMBER OF CEOs referring to the number of directors in definition A, B, C, respectively.

We have been able to classify CEOs according to whether they are controlling shareholders. To do so we integrate information about ownership structure ${ }^{9}$ with recent company history from Taccuino dell'Azionista and Sole 24 Ore. We have thus constructed the dummy variable, CEO OWNERSHIP, which takes value 1 when the CEO is a controlling shareholder or a member of the controlling family, and 0 otherwise. Lack of suitable information prevents us from determining whether the other directors are controlling shareholders, and more generally, from determining directors' share ownership. In particular we have no direct information about managerial ownership as such, and ownership disclosure is mandatory only for shares exceeding $2 \%$ of firm capital.

Performance Measures: We use both accounting-based and market-based firm performance measures. As accounting-based performance measures we use the growth rate of sales (SALES) and the growth rate of operating income measured as earnings before interest, taxes, depreciation and amortization (EBITDA). We choose the latter variable because it cannot be as easily manipulated as other performance measures (e.g. net earnings) which, for example, allow some degree of choice of the depreciation and the tax regime.

In addition to these accounting-based variables we use STOCK RETURN, defined as the sum of the percentage capital gain in a year plus the dividend yield for that year, 
corrected to take into account changes in nominal capital (e.g. stock splits, free distributions of stocks, rights issues, etc.). All these measures refer to changes occurring between year $t-1$ and year $t$.

We allow for a nonlinear relationship between turnover and firm performance by using the product between a variable and its absolute value, for each performance variable. This transformation maintains the sign of the variable.

Company Information: We use the following information on the companies in the sample: SIZE (the logarithm of the number of employees), STATE OWNERSHIP (a dummy variable equal to 1 if the company is state owned, and to 0 otherwise). The information about ownership structure consists of the percentage of common shares held by both the LARGEST SHAREHOLDER and by the SECOND SHAREHOLDER. ${ }^{10}$ The aforementioned $2 \%$ disclosure threshold makes it difficult to identify second largest shareholders when they are small. Missing values of the shares of the second shareholders (less than $3 \%$ of the observations) have been conventionally assigned a share $1.99 \%$. SYNDICATE is a dummy variable equal to 1 if the main shareholders are linked by a shareholders syndicate, and to 0 otherwise. The information on CEO OWNERSHIP is used to construct the dummy variable FAMILY OWNERSHIP, which assigns value 1 to firms that had the CEO as a controlling shareholder or as a member of the controlling family in at least one year, and 0 otherwise.

To determine whether turnover is sensitive to change in control, we have classified firms according to whether they have experienced a change in control. To this end we define the dummy variable, CONTROL CHANGE, that takes value 1 if the firm

\footnotetext{
${ }^{9}$ See the Subsection on Company information.

${ }^{10}$ Beside common shares, our firms often have two other types of shares outstanding: Preference shares (with or without voting rights, and with higher dividend rights); Saving shares (without voting rights but with predetermined dividend rights and dividend priority over the other types of share). We only have information on common shares.
} 
experienced at least one change in control during the period 1988-96, and 0 otherwise. This variable, a proxy of the contestability of company control, is constructed by using the information on the controlling shareholder provided by Taccuino dell'Azionista, and excludes transfers of control within the same group. By construction, FAMILY OWNERSHIP and CONTROL CHANGE do not vary over time for each firm in the sample.

Finally FIRM AGE is computed as 1995 minus the year the firm was established. Table 1 provides a summary of the variables, their definition, and their source.

\section{[INSERT TABLE 1 ABOUT HERE]}

\section{Summary statistics}

Table 2 reports summary statistics on the personal characteristics of the directors in our sample $^{11}$. The average age is between 55 and 59 , depending on the position. Average tenure in the board is more than four years. Recall that directors are appointed for a renewable three-year term. The percentage of women in the entire board is very small (3\%) and decreases further when we consider Top Executives and CEOs. Generally, the few women on a board are members of the controlling family. Directors often sit on the board of more than one firm. Interlocking membership is a common feature in companies that belong to a pyramidal group and are controlled through a shareholder syndicate. In our sample directors hold an average of 1.30 outside directorships, a value that falls to 1.07 for CEOs. This is consistent with the notion that the opportunity cost of outside directorships is higher for managers with greater marginal products, which is often the case of CEOs. Finally, the table shows that more than one quarter of CEOs are controlling shareholders or members of the controlling family.

\section{[INSERT TABLE 2 ABOUT HERE]}

Table 3 shows the average number of board directors according to the different measures of board membership (A, B and C). Top Executives (definition B) are almost 30\% of all 
board members. Not reported in the table is the difference between the average board size of private companies (9.5 members) and of state-owned companies (12.8 members).

\section{[INSERT TABLE 3 ABOUT HERE]}

Table 4 shows average turnover by ownership characteristics of firms. The percentage of directors leaving the board in a given year ranges from 11 to $14 \%$, depending on the definition used (A, B or $C)$.

\section{[INSERT TABLE 4 ABOUT HERE]}

Turnover is lower in family-owned firms where the largest shareholder holds less than the average percentage of common shares (54\%), and where the second shareholder has more than the average percentage of common shares (9\%), and almost always lower in firms with a shareholder syndicate. These differences are largest for turnover $\mathrm{C}$, the turnover of the CEOs. Therefore, family control, shareholder syndicate, and a large second shareholder make the board of directors, and in particular the position of the CEO more stable. However, the presence of a large main shareholder makes the board less stable.

Table 5 Panel A shows that, for all the three definitions, turnover in companies which have experienced at least one change of control in the sample period is more than twice as large as turnover in companies that have not. Panel B shows that average turnover, measured as the average of turnover between year $t-1$ and year $t$ and turnover between year $t$ and $t+1$, increases in the years around control change, which occurs in year $t$. This increase is strongest for measure A. Panel B also suggests that firms with a control change always have a less stable board, both in the years around the control change and in the other years. Not reported in the tables is that in $78 \%$ of the companies that have experienced a change in control, the largest shareholder owned more than $50 \%$ of the shares in the year of control change. We conjecture that the larger the share of the

\footnotetext{
${ }^{11}$ The number of observations varies across the columns for two reasons: first, there are firms and years with
} 
main shareholder, the easier the transfer of control. Transfer of control, in turn, leads to board changes as suggested by Table 5 Panel B.

\section{[INSERT TABLE 5 ABOUT HERE]}

As shown in Table 6 concentrated ownership is very common in Italy also among listed firms. $^{12}$ In our sample the largest shareholder owns on average more than $50 \%$ of common shares. Note also that the median of the largest shareholding is above $50 \%$, thus indicating that in more than half of the firms the largest shareholder owns the absolute majority of common shares. These values are very stable over time.

\section{[INSERT TABLE 6 ABOUT HERE]}

The average percentage of shares held by the second largest shareholder is between 8 and $10 \%$ and remains stable over time. This suggests that in the firms in our sample there is often no other large shareholder to monitor the main shareholder. ${ }^{13}$ Table 6 also presents the number of firms with a shareholder syndicate and shows that the percentage of common shares in the syndicate is, on average, slightly above $50 \%$, and stable over time.

Finally, Table 7 shows the summary statistics of firm performance variables. In 1995 average sales in our sample were 3,786 billion lire, and the average number of employees was 11,590 , thus suggesting that most of these firms are large companies by Italian standards.

\section{[INSERT TABLE 7 ABOUT HERE]}

\section{Empirical results}

This section presents the results of regressions of turnover measures on three sets of

no CEO or top executives; second, there are years where information on age is missing.

${ }_{12}$ Similar findings are reported by Bianco and Casavola (1999) and Bianchi et. al. (1998) for listed companies. In 1996 the largest shareholder and the largest three shareholders owned $48 \%$ and $62 \%$ of the shares, respectively. Institutional investors hold a small fraction of the equity of Italian firms: in 1997 mutual funds stocks ownership was $6 \%$ of the Milan Stock Exchange capitalization. That ratio was $5 \%$ for insurance companies, $0.5 \%$ for pension funds, $0.2 \%$ for stockbrokers (S.I.M.) (Banca d' Italia 1998).

${ }^{13}$ For a similar result see La Porta et al. (1999, Table 7). They show that in all top 20 Italian companies by stock market capitalization there is no other shareholder with at least $10 \%$ of the shares as a potential 
explanatory variables: firm performance measures (SALES, EBITDA, STOCK RETURN), board characteristics (AGE, TENURE, NUMBER OF DIRECTORSHIPS, BOARD SIZE, NUMBER OF TOP EXECUTIVES, NUMBER OF CEOS, CEO OWNERSHIP), and firm characteristics (STATE OWNERSHIP, LARGEST SHAREHOLDER, SECOND SHAREHOLDER, SYNDICATE, CONTROL CHANGE, SIZE, FAMILY OWNERSHIP).

Since our data are firm specific, variations in turnover rates across firms depend, in general, both on fixed and on time-varying effects. More in detail, let our turnover equations be specified as follows

$$
\text { XOXYU }=\alpha_{i}+\beta\left[{ }_{i t}+\gamma\right]_{t}+\varepsilon_{i t}
$$

where $i$ is for firms and $t$ for time, turnover is a dummy equal to 1 if turnover takes place, and to zero otherwise; $x$ is a vector of variables that change both over time and across firms; $z$ is a vector of variables that vary only over time; $\varepsilon$ is an error term; and $\alpha$ is a firm specific and time invariant effect. When $\alpha$ captures unobserved or unmeasured firm characteristics, ignoring these effects in estimation leads to biased results (Greene, 1983). We deal with this problem by introducing firm specific dummies in the regression.

The use of firm specific dummies also captures the time invariant component of the selection mechanism that allocates firms to "stayers" (always in the sample from 1988 to 1996) and "leavers" (firms that are quoted on the Italian Stock Exchanges for only part of the sample period). Notice that the inclusion of firm dummies means that the empirical analysis focuses exclusively on firms that have experienced variations in their turnover over time.

Assuming that the error term $\varepsilon$ has a normal distribution, we estimate the following probit model

$$
\operatorname{Pr}\left(\text { turnover }_{i t}=1\right)=\Phi\left(Z^{\prime} b\right)
$$

monitor of the controlling shareholder. 
where $Z$ is the vector of explanatory variables. We assign to the dummy variable TURNOVER the value 1 when the percentage of CEO turnover in the firm is higher than zero, and the value 0 otherwise ${ }^{14}$. All regressions include time dummies that control for economy-wide shocks, including aggregate price dynamics. The tables with results report neither the coefficients of these dummies nor the coefficients of firm specific dummies.

We use three firm performance indicators: two accounting-based indicators (SALES, EBITDA) and one market-based indicator, STOCK RETURN. Recall that we cannot identify and exclude from our data set turnover instances due to retirement. To eliminate many instances of retirement turnover we focus only on directors aged under 71 . To further take into account turnover due to retirement, we introduce both $A G E$ and TENURE in the regressions.

We test Hypothesis 1 by introducing in the regressions the variable CEO OWNERSHIP and by interacting the performance variables with the variable FAMILY OWNERSHIP. We test the effect of ownership structure on turnover (Hypotheses 3 and 5) by including the following variables: LARGEST SHAREHOLDER, SECOND SHAREHOLDER and SYNDICATE.

The performance variables are also interacted with CONTROL CHANGE to test Hypothesis 2 and with STATE OWNERSHIP to test Hypothesis 6 . Finally, to test Hypothesis 4 we construct a dummy indicating whether the second shareholder has above average holdings, and we interact the performance variables with this dummy.

As shown in Table 4, directors hold on average more than one directorship. It has been argued that interlocking directorships might lead to collusive behavior between directors. We test whether it is more difficult to remove directors with several outside directorships by using the variable NUMBER OF DIRECTORSHIPS.

\footnotetext{
${ }^{14}$ We have also run ordered probit regressions where TURNOVER is allowed to take more than 2 values,
} 


\section{Turnover Estimates}

For each turnover measure we run separate regressions using the three different performance variables, after excluding all the observations with variations of performance larger than $200 \%$ in absolute value, which are clear outliers ${ }^{15}$. In Tables 8 and 11 we report the estimates for turnover C (CEO turnover). In the Appendix, we also report the results for turnover A and B (board turnover and top executives turnover, respectively).

Columns 1-3 of Table 8 report the coefficients of the regressions of turnover $\mathrm{C}$ on the three selected performance measures. We find that turnover is negatively and significantly related to all three measures of performance. Therefore, a decrease in EBITDA and SALES and in the STOCK RETURN between year $t-1$ and year $t$ increases the probability of CEO turnover between year $t$ and year $t+1$.

The relationship between turnover $\mathrm{C}$ and firm performance is not linear, as shown by the positive coefficients attracted by the product of the selected performance measure and its absolute value. Therefore, a negative change in the performance variable(s) increases the probability of turnover of CEOs, but this effect is larger the smaller the absolute value of this change.

Table 9 shows the marginal change in the probability of turnover when there is a marginal percentage change in firm performance, evaluated at the average value of the selected performance measure ${ }^{16}$. The table suggests that the estimated probability of turnover is very sensitive to changes in firm performance. For instance, suppose that sales growth increases by $20 \%$, from 5 to $6 \%$ a year. This increase implies a reduction in the probability of turnover $\mathrm{C}$ close to 1 , clearly sufficient to eliminate turnover altogether.

with no significant changes in the results.

${ }^{15}$ This amounts to excluding 3 observations in the case of SALES and 31 observations in the case of EBIDTA.

${ }^{16}$ Let $y=\Phi(b x+c x|x|)$. The marginal effect computed in the tables is $\frac{\partial y}{\partial \ln x}=\phi[b+2 c|x|] x$, where $\phi$ is the density function and both $x$ and $|x|$ are evaluated at their sample mean. 
Next assume that stock returns increase by $50 \%$, from 4 to $6 \%$ a year. In this case, the predicted decline in the probability of turnover $\mathrm{C}$ is 0.7 .

Given that the estimated probability of turnover is very sensitive to changes in our measures of performance, an interesting question is whether this sensitivity is associated to ownership changes. Columns $4-6$ of Table 8 address this question by adding to the baseline regressions the interaction of our measures of performance with the dummy CONTROL CHANGE. ${ }^{17}$

The last two rows in the table show the probability values of the likelihood ratio tests for the joint hypothesis that the coefficients of the performance variables are significantly different from zero (second-last) and that the coefficients of the interactions of performance with CONTROL CHANGE are significantly different from zero (last row). It turns out that for two measures of performance (SALES and EBITDA) out of the selected three the relationship between turnover $\mathrm{C}$ and performance is significant only among firms that have experienced at least one change of control over the sample period. For the remaining measure (STOCK RETURM) this relationship is significant also among firms which have experienced no control change. In contrast to the results based on accounting measures, we find that the sensitivity of turnover to changes in stock returns is largest among firms with no ownership change.

To illustrate, consider for instance the effects of $1 \%$ increase in SALES on turnover C. This increase reduces the probability of turnover by 0.026 in firms that have never changed ownership and by 0.083 in firms that have changed ownership. Next consider a $1 \%$ increase in STOCK RETURN. In this case, turnover is predicted to decline by 0.019 for firms with no ownership change and by only 0.011 for firms with at least an ownership change.

${ }^{17}$ Clearly the division of firms into those firms with at least an experience of change in control and firms without such experience is not random. The firm specific factors regulating the allocation are captured in the regressions by the firm specific dummies. 
Clearly, ownership change is not an exogenous event. Table 10 presents the results of the probit regression of the dummy CONTROL CHANGE on the average age of the firm, on the average share of the larger shareholder and on average firm performance, measured by the average value of SALES in the sample period. We find that the probability of a change of control during the sample period increases with the age of the firm, with the relative importance of the largest shareholder and decreases with average performance. In particular, we estimate that a $1 \%$ increase in average SALES reduces the probability of a change in control by 0.126 , a significant decline.

Since ownership change is significantly associated to poor average performance, our results suggest that firms performing poorly with respect to the average are more likely both to experience ownership changes and to have higher managerial turnover.

Independently of our measure of firm performance, the NUMBER OF CEOs attracts a statistically significant and positive coefficient. This finding suggests that firms with a larger number of CEOs also have higher turnover rates. One possible explanation is that the larger the number of CEOs, the lower their shareholding and the easier it is to remove them. Another explanation is that the degree of substitutability of top executives is higher in larger boards, which facilitates turnover ${ }^{18}$.

The coefficient of SIZE is never significant, thus suggesting that small and large firms exhibit similar turnover. While average AGE is never significant, average TENURE attracts a significant coefficient ${ }^{19}$. In particular, turnover is higher the greater the number of years spent by the CEOs in that position. One reason is that managerial contracts last usually three years.

The NUMBER OF DIRECTORSHIPS is never significant and therefore we have to reject the hypothesis that the higher the number of outside directorships the more

\footnotetext{
${ }^{18}$ The positive relationship between turnover and number of directors holds also for turnover $\mathrm{A}$ and $\mathrm{B}$, as shown in the Appendix.

${ }^{19}$ This result does not hold for the other two measures of turnover.
} 
important the director, and the more difficult it is to remove him/her. STATE OWNERSHIP is also never significant, thus indicating that turnover is unrelated to whether the firm is private or state owned.

While the coefficient associated to the LARGEST SHAREHOLDER is almost never significant, the coefficient associated to the SECOND SHAREHOLDER is significant and negative in almost all regressions for turnover $\mathrm{C}$. The fact that the coefficient of the largest shareholder is almost never significant and that therefore we have to reject Hypothesis 4 might be related to the presence of two contrasting effects that cancel out. On the one hand, high inside ownership induces high monitoring and high turnoverperformance sensitivity. On the other hand, high inside ownership induces entrenchment, low turnover-performance sensitivity, and a low turnover.

Next, the coefficient associated to the variable SYNDICATE is almost never significant and therefore we have no evidence in our sample that companies with a syndicate among the largest shareholders have lower probability of turnover contrary to our Hypothesis 5. This is in contrast with the descriptive evidence reported in Table 4.

The coefficient of the variable CEO OWNERSHIP turns out to be negative and significant in most of our regressions. Since this dummy is a proxy of family ownership, we interpret this result as indicative of the fact that family-controlled firms have on average lower turnover than other firms. This result is consistent with the descriptive facts presented in Table 4 and with our Hypothesis 1. This hypothesis also states that the sensitivity of turnover to performance should be lower in family-controlled firms. This part of the hypothesis is not supported by our findings. Columns 1-3 of Table 11 present the results of the regressions with the performance variables interacted with the dummy FAMILY OWNERSHIP. The interactions are statistically significant only in the regression with STOCK RETURN as performance variable and indicate that family-controlled firms have a higher turnover performance sensitivity, contrary to our hypothesis. 
In the last three columns of Table 11 we test our hypothesis on the monitoring role of the second shareholder by interacting the performance variables with a dummy that takes value 1 when the second shareholder has an above average share of stocks in the firm. In two out of three regressions we find that firms where the second shareholder has an above average share have a stronger turnover performance relationship. Thus, our findings are consistent with Hypothesis 4. Finally Table 12 shows the regressions that include the interactions between the performance variables and the dummy STATE OWNERSHIP. These interactions always attract a positive coefficient and are significant when performance is measured either by EBIDTA or by STOCK RETURN. This indicates that state-owned firms have a much weaker association between CEOs turnover and firm performance, consistent with Hypothesis 6.

The basic regressions (without interactions) for turnover $A$ and $B$ are presented in the Appendix. Table A1 shows that there is a statistically significant and negative relationship between turnover of top executives (turnover B) and two of our performance measures, EBITDA and STOCK RETURN. The coefficient of SALES attracts instead a negative sign but it is not statistically significant. Tables $A 1 b$ shows that the sensitivity to a marginal change in the statistically significant performance variables is similar for turnover B and for turnover $\mathrm{C}$.

The regressions for the turnover of the entire board (turnover A) are presented in Table A2a. Here, none of the performance variables is statistically significant; thus indicating that board turnover is unrelated to firm performance. Contrary to what we found for turnover $\mathrm{C}$ and $\mathrm{B}$, both the largest shareholder and the second shareholder attract a negative and statistically significant coefficient, suggesting that the entrenchment effect may be valid only for directors who are not top executives. 


\section{Summary}

We have studied the turnover of board directors in a sample of Italian listed companies. We have focused mainly on the turnover of CEOs (measure C), but have also considered the turnover of the entire board (measure A) and the turnover of the President, Vice-President, General Manager and CEO (measure B).

We have found that there is a statistically significant and negative relationship between firm performance and CEOs turnover. Importantly, this relationship depends on the ownership structure of firms. As suggested by Hypothesis 1 we have found that familycontrolled firms have a lower turnover. However, there is no evidence that these firms have lower turnover performance sensitivity; when firm performance is measured by STOCK RETURN we find that the CEOs turnover-performance sensitivity is stronger in family-controlled companies.

An interesting finding is that the turnover-performance relationship, regardless of how performance is measured, is higher in firms that experienced at least one change in control during the sample period. We have also shown that change in control is negatively associated with performance. We interpret these results as supporting our hypothesis that control change is an extreme instance of turnover (Hypothesis 2). The turnover performance relationship is also stronger in companies where the second shareholder has above average holdings. This suggests that the second shareholder plays an active monitoring role (Hypothesis 4). State-owned companies have a much weaker turnover performance relationship, thus confirming that these companies have different objectives from value maximization (Hypothesis 5). Finally, we have found that the turnover of top executives exhibits a negative but weaker relationship with firm performance and that board turnover is not associated with performance.

The economic and institutional environment in which our firms operate differ greatly from the Anglo-Saxon one. It is, however, by no means the only example of this kind of 
situation. It is therefore legitimate to suppose that the questions we have addressed in this paper are of general interest and go beyond the specific country study. 


\begin{tabular}{|c|c|c|}
\hline Variable & Description & Source \\
\hline \multicolumn{3}{|c|}{ Panel A: Board Characteristics } \\
\hline AGE & $\begin{array}{l}\text { Average age of directors in each definition } \\
(A, B \text { and } C) \text {. }\end{array}$ & Company filings with CONSOB \\
\hline TENURE & $\begin{array}{l}\text { Years spent in the board of a given company } \\
\text { by directors in each definition }\end{array}$ & Company filings with CONSOB \\
\hline $\begin{array}{l}\text { NUMBER OF } \\
\text { DIRECTORSHIPS }\end{array}$ & $\begin{array}{l}\text { Average number of positions held in other } \\
\text { boards by directors in each definition }\end{array}$ & Company filings with CONSOB \\
\hline CEO OWNERSHIP & $\begin{array}{l}\text { A dummy variable }=1 \text { when the CEO is a } \\
\text { controlling shareholder or a member of the } \\
\text { controlling family, and } 0 \text { otherwise. }\end{array}$ & $\begin{array}{l}\text { Authors' classification based on } \\
\text { Taccuino dell'Azionista }\end{array}$ \\
\hline TURNOVER A & $\begin{array}{l}\text { Turnover of all board members: } \\
\text { the \% of directors of a given board leaving } \\
\text { the board in a given year. }\end{array}$ & Calepino dell'Azionista \\
\hline TURNOVER B & $\begin{array}{l}\text { Turnover of Top Executives (President, Vice } \\
\text { President, CEO and General Manager): the } \\
\% \text { of top executives of a given board leaving } \\
\text { the board in a given year. }\end{array}$ & Calepino dell'Azionista \\
\hline TURNOVER C & $\begin{array}{l}\text { Turnover of CEOs: the \% of CEO of a given } \\
\text { board leaving the board in a given year. }\end{array}$ & Calepino dell'Azionista \\
\hline BOARD SIZE & Number of all directors on the board. & Calepino dell'Azionista \\
\hline $\begin{array}{l}\text { NUMBER OF TOP } \\
\text { EXECUTIVES }\end{array}$ & $\begin{array}{l}\text { Number of Top Executives (President, Vice } \\
\text { President, CEO and General Manager) }\end{array}$ & Calepino dell'Azionista \\
\hline NUMBER OF CEOS & Number of CEOs & Calepino dell'Azionista \\
\hline \multicolumn{3}{|c|}{ Panel B: Firm Performance Measures } \\
\hline SALES & Annual growth of sales & Calepino dell'Azionista \\
\hline EBITDA & $\begin{array}{l}\text { Annual growth of earnings, before interest, } \\
\text { taxes, depreciation and amortization. }\end{array}$ & Calepino dell'Azionista \\
\hline STOCK RETURN & $\begin{array}{l}\text { Defined as the sum of the percentage capital } \\
\text { gain in a year and of the dividend yield for } \\
\text { that year, corrected to take into account } \\
\text { changes in nominal capital (e.g. stock splits, } \\
\text { free distributions of stocks, rights issues, } \\
\text { etc.) }\end{array}$ & $\begin{array}{l}\text { Sole } 24 \text { Ore, R\&S, Taccuino } \\
\text { dell'Azionista }\end{array}$ \\
\hline \multicolumn{3}{|c|}{ Panel C: Firm Characteristics } \\
\hline $\begin{array}{l}\text { LARGEST } \\
\text { SHAREHOLDER }\end{array}$ & $\begin{array}{l}\text { Percentage of common shares held by largest } \\
\text { shareholder. }\end{array}$ & $\begin{array}{l}\text { Company filings with CONSOB and } \\
\text { Taccuino dell'Azionista }\end{array}$ \\
\hline $\begin{array}{l}\text { SECOND } \\
\text { SHAREHOLDER }\end{array}$ & $\begin{array}{l}\text { Percentage of common shares held by } \\
\text { second largest shareholder. }\end{array}$ & $\begin{array}{l}\text { Company filings with CONSOB and } \\
\text { Taccuino dell'Azionista }\end{array}$ \\
\hline FIRM AGE & Firm age in 1995 since company foundation & Taccuino dell'Azionista \\
\hline $\begin{array}{l}\text { STATE } \\
\text { OWNERSHIP }\end{array}$ & $\begin{array}{l}\text { A firm dummy variable }=1 \text { if the firm is state } \\
\text { owned, and } 0 \text { otherwise. }\end{array}$ & Taccuino dell'Azionista \\
\hline $\begin{array}{l}\text { FAMILY } \\
\text { OWNERSHIP }\end{array}$ & $\begin{array}{l}\text { A firm dummy variable assigning } 1 \text { to firms } \\
\text { where in at least one year the CEO is a } \\
\text { controlling shareholder or a member of the } \\
\text { controlling family. }\end{array}$ & $\begin{array}{l}\text { Authors' classification based on } \\
\text { Taccuino dell'Azionista }\end{array}$ \\
\hline SYNDICATE & $\begin{array}{l}\text { A firm dummy variable }=1 \text { if the main } \\
\text { shareholders are linked by a shareholder } \\
\text { syndicate, and } 0 \text { otherwise. }\end{array}$ & $\begin{array}{l}\text { Company filings with CONSOB and } \\
\text { Taccuino dell'Azionista }\end{array}$ \\
\hline SIZE & Logarithm of number of employees & Calepino dell'Azionista \\
\hline CONTROL CHANGE & $\begin{array}{l}\text { A firm dummy variable }=1 \text { if the firm } \\
\text { experienced at least one change in control } \\
\text { in the years considered, and } 0 \text { otherwise. }\end{array}$ & $\begin{array}{l}\text { Authors' classification based on } \\
\text { Taccuino dell'Azionista and } \\
\text { company filings with CONSOB }\end{array}$ \\
\hline
\end{tabular}




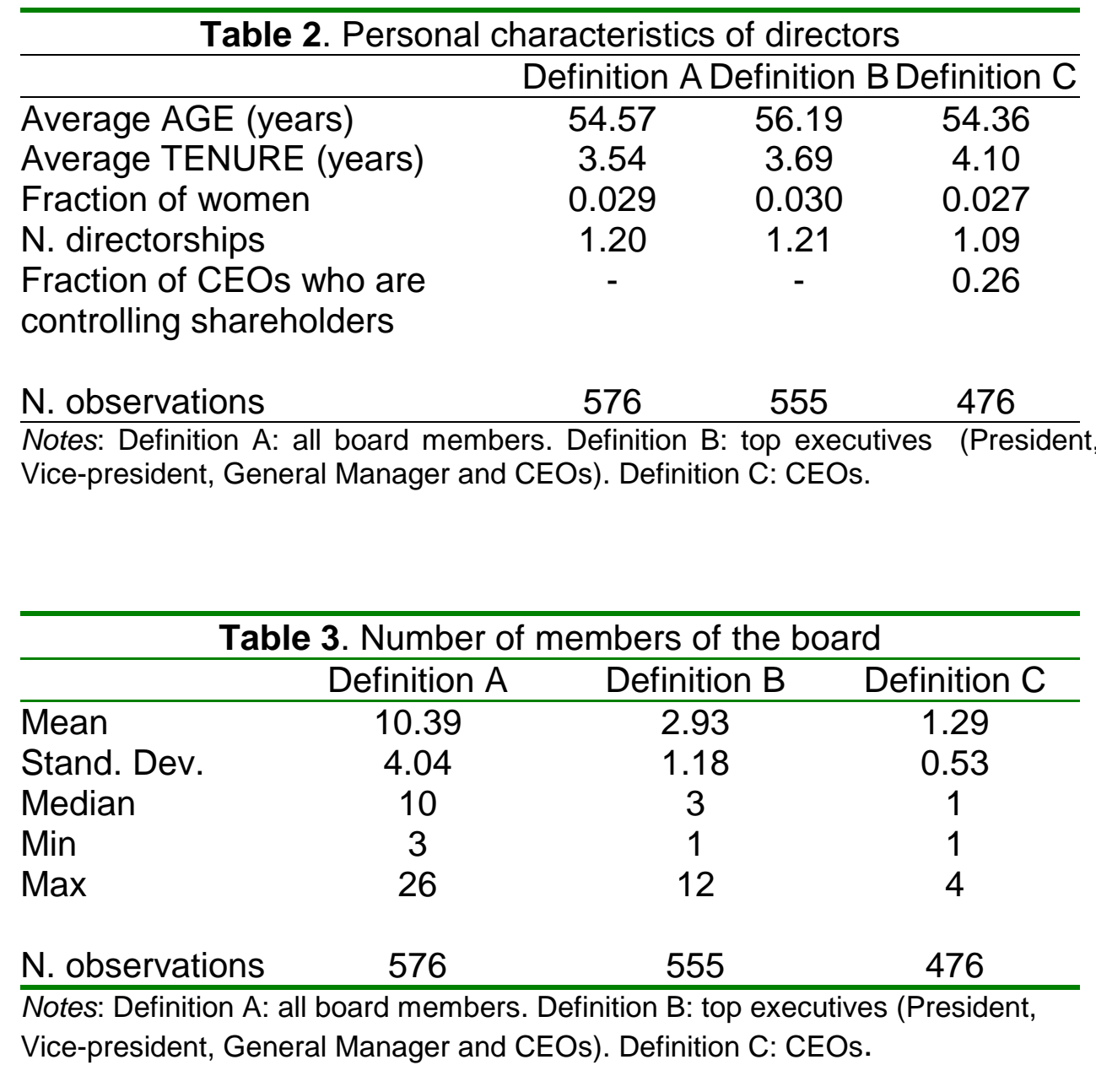

\begin{tabular}{|c|c|c|c|}
\hline & A & $B$ & C \\
\hline All firms & 13.78 & 10.66 & 11.96 \\
\hline $\begin{array}{l}\text { Family owned } \\
\text { Not family owned }\end{array}$ & $\begin{array}{l}11.62 \\
14.99\end{array}$ & $\begin{array}{c}7.74 \\
12.33\end{array}$ & $\begin{array}{c}7.49 \\
14.64\end{array}$ \\
\hline $\begin{array}{l}\text { With Syndicate } \\
\text { Without Syndicate }\end{array}$ & $\begin{array}{l}13.05 \\
14.03\end{array}$ & $\begin{array}{c}6.87 \\
11.97\end{array}$ & $\begin{array}{c}7.43 \\
13.49\end{array}$ \\
\hline $\begin{array}{l}\text { Largest shareholder owns }{ }^{*} \text { : } \\
>54 \% \text { of shares } \\
\leq 54 \% \text { of shares }\end{array}$ & $\begin{array}{l}16.28 \\
11.27\end{array}$ & $\begin{array}{l}12.90 \\
8.45\end{array}$ & $\begin{array}{c}14.84 \\
9.19\end{array}$ \\
\hline $\begin{array}{l}\text { Second shareholder owns } \\
>9 \% \text { of shares } \\
\leq 9 \% \text { of shares }\end{array}$ & $\begin{array}{l}10.72 \\
15.61\end{array}$ & $\begin{array}{c}5.93 \\
13.44\end{array}$ & $\begin{array}{c}7.34 \\
14.47\end{array}$ \\
\hline
\end{tabular}

Notes: ${ }^{*} 54 \%$ and $9 \%$ are the average share holdings of the largest shareholder, and of the second shareholder, respectively. 
Table 5. Turnover and change of control

Turnover Turnover Turnover

A B C

\begin{tabular}{llll}
\hline Panel $A$ & & & \\
\hline $\begin{array}{l}\text { Firms: } \\
\text { With control change }\end{array}$ & 24.41 & 20.58 & 19.39 \\
$\quad$ Without control change & 10.37 & 7.07 & 7.35 \\
& & & \\
\hline Panel B & & & \\
\hline $\begin{array}{l}\text { Firms with control change: } \\
\text { In years around control } \\
\text { change }\end{array}$ & 40.42 & 34.91 & 29.16 \\
$\quad$ In other years & 21.56 & 18.03 & 17.65 \\
\hline
\end{tabular}

Table 6. Largest shareholders and Shareholders syndicate $\begin{array}{lllllllll}1988 & 1989 & 1990 & 1991 & 1992 & 1993 & 1994 & 1995 & 1996\end{array}$

Percentage of shares of largest shareholder

$\begin{array}{llllllllll}\text { Average } & 53,0 & 54,6 & 53,6 & 54,2 & 56,1 & 56,1 & 54,3 & 54,3 & 55,2 \\ \text { Minimum } & 5,2 & 10,6 & 16,6 & 13,7 & 16,6 & 14,2 & 14,2 & 14,2 & 9,3 \\ \text { Maximum } & 92,8 & 91,9 & 91 & 94,3 & 92,4 & 100 & 100 & 100 & 100 \\ \text { Median } & 54,1 & 54,0 & 51,1 & 54,2 & 53,9 & 57,6 & 53,9 & 54,3 & 54,3\end{array}$

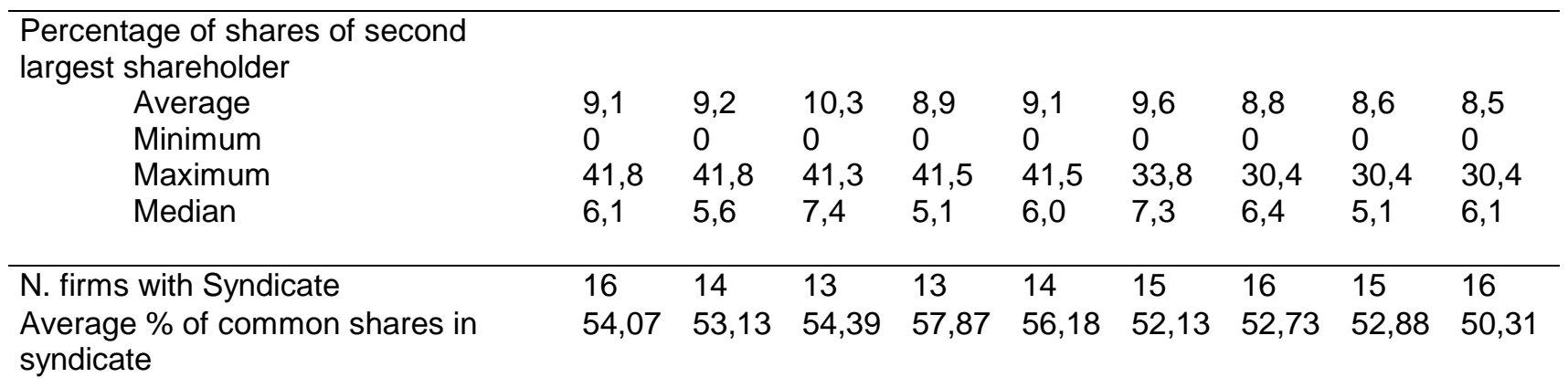

Note: N. of firms 72.

Table 7. Firm characteristics, 1995

\begin{tabular}{|c|c|c|c|c|c|c|c|}
\hline & SALES* & EBITDA $^{*}$ & $\begin{array}{l}\text { STOCK } \\
\text { RETURN } \\
(\%)\end{array}$ & $\begin{array}{l}\begin{array}{l}\text { FIRM AGE } \\
\text { (years) }\end{array}\end{array}$ & $\begin{array}{l}\text { NUMBER OF } \\
\text { EMPLOYEES }\end{array}$ & $\begin{array}{l}\text { FRACTION OF } \\
\text { STATE-OWNED } \\
\text { COMPANIES }\end{array}$ & $\begin{array}{l}\text { STOCK MARKET } \\
\text { CAPITALIZATION } \\
\text { IN } 1995^{*}\end{array}$ \\
\hline Mean & 3,785 & 886.9 & -11 & 76.5 & 11,590 & 0.15 & 1,585 \\
\hline Median & 853 & 77.9 & -13 & 77 & & & 234 \\
\hline N. observ. & 72 & 72 & 72 & 72 & 72 & 72 & 72 \\
\hline
\end{tabular}

Note: * Billion lire, 1995 prices. 


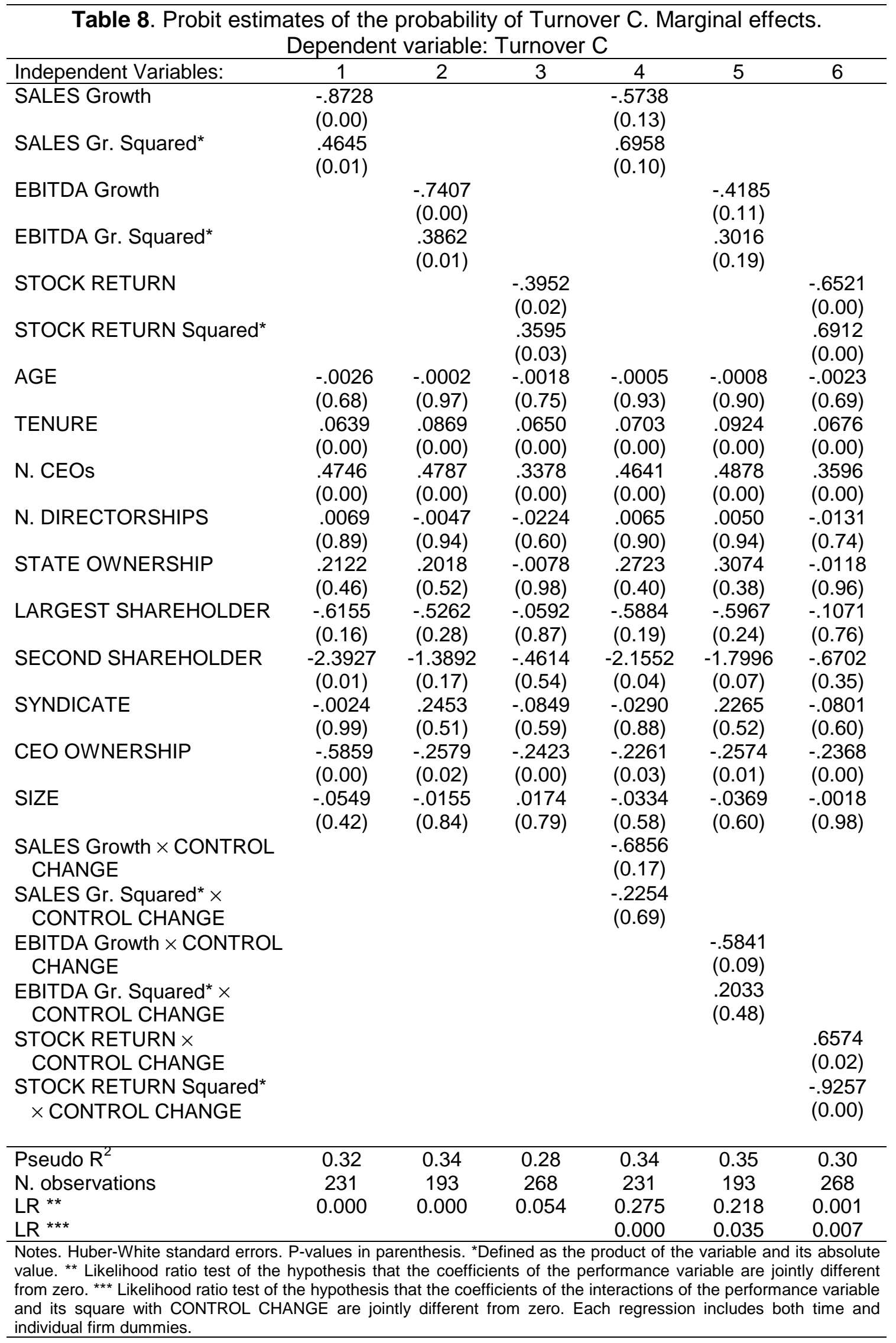


Table 9. Changes in the probability of turnover $\mathrm{C}$ induced by a percentage change in the performance measure: $\frac{\partial \Phi}{\partial \ln x}$. Without interactions and with interaction with CONTROL CHANGE.

\begin{tabular}{|c|c|c|c|c|c|c|}
\hline 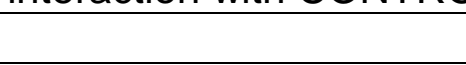 & 1 & 2 & 3 & 4 & 5 & 6 \\
\hline SALES Growth & -.054 & & & & & \\
\hline EBITDA Growth & & -.018 & & & & \\
\hline STOCK RETURN & & & -.014 & & & \\
\hline $\begin{array}{l}\text { SALES Growth } \times \\
\text { CONTROL CHANGE }=0\end{array}$ & & & & -.026 & & \\
\hline $\begin{array}{l}\text { SALES Growth } \times \\
\text { CONTROL CHANGE }=1\end{array}$ & & & & -.083 & & \\
\hline $\begin{array}{l}\text { EBITDA Growth } \times \\
\text { CONTROL CHANGE }=0\end{array}$ & & & & & -.008 & \\
\hline $\begin{array}{l}\text { EBITDA Growth } \times \\
\text { CONTROL } \text { CHANGE }=1\end{array}$ & & & & & -.024 & \\
\hline $\begin{array}{l}\text { STOCK RETURN } \times \\
\text { CONTROL CHANGE }=0\end{array}$ & & & & & & -.019 \\
\hline $\begin{array}{l}\text { STOCK RETURN } \times \\
\text { CONTROL CHANGE }=1\end{array}$ & & & & & & -.011 \\
\hline
\end{tabular}

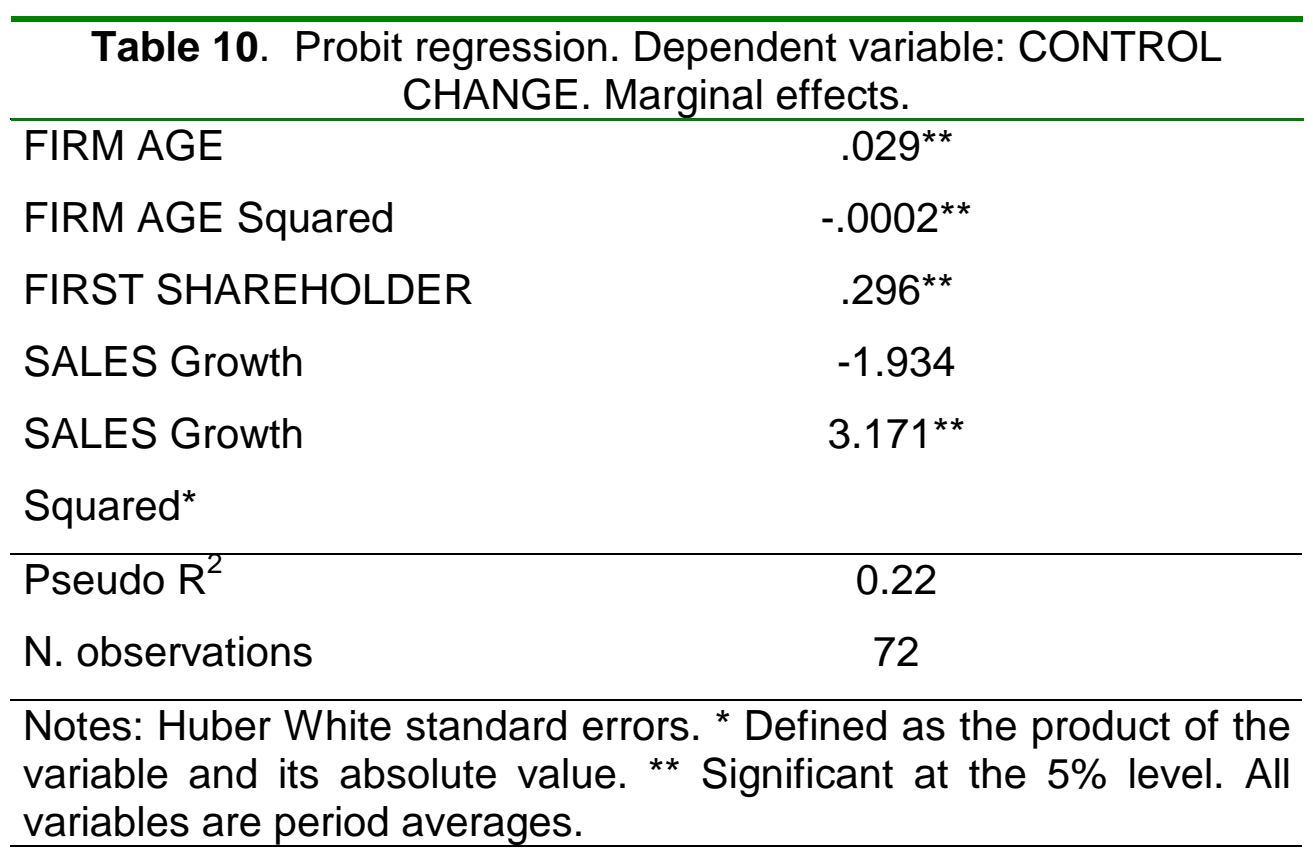


Table 11. Probit estimates of the probability of Turnover C. Additional interactions. Marginal effects. Dependent variable: Turnover C

\begin{tabular}{|c|c|c|c|c|c|c|}
\hline Independent Variables: & 1 & 2 & 3 & 4 & 5 & 6 \\
\hline SALES Growth & $\begin{array}{l}-.7303 \\
(0.07)\end{array}$ & & & $\begin{array}{l}-.7325 \\
(0.33)\end{array}$ & & \\
\hline SALES Gr. Squared* & $\begin{array}{l}-.4338 \\
(0.64)\end{array}$ & & & $\begin{array}{l}-.0797 \\
(0.97)\end{array}$ & & \\
\hline EBITDA Growth & & $\begin{array}{c}-.5497 \\
(0.02)\end{array}$ & & & $\begin{array}{l}-.8638 \\
(0.00)\end{array}$ & \\
\hline EBITDA Gr. Squared* & & $\begin{array}{l}.2010 \\
(0.37)\end{array}$ & & & $\begin{array}{l}.6580 \\
(0.00)\end{array}$ & \\
\hline STOCK RETURN & & & $\begin{array}{l}-.2104 \\
(0.21)\end{array}$ & & & $\begin{array}{c}-.5408 \\
(0.02)\end{array}$ \\
\hline STOCK RETURN Squared* & & & $\begin{array}{l}.2423 \\
(0.16)\end{array}$ & & & $\begin{array}{l}.6905 \\
(0.00)\end{array}$ \\
\hline AGE & $\begin{array}{l}-.0023 \\
(0.70)\end{array}$ & $\begin{array}{c}-.0019 \\
(0.79)\end{array}$ & $\begin{array}{r}-.0024 \\
(0.67)\end{array}$ & $\begin{array}{c}-.0022 \\
(0.73)\end{array}$ & $\begin{array}{l}-.0029 \\
(0.66)\end{array}$ & $\begin{array}{l}-.0019 \\
(0.74)\end{array}$ \\
\hline TENURE & $\begin{array}{l}.0628 \\
(0.00)\end{array}$ & $\begin{array}{l}.0845 \\
(0.00)\end{array}$ & $\begin{array}{l}.0629 \\
(0.00)\end{array}$ & $\begin{array}{l}.0645 \\
(0.00)\end{array}$ & $\begin{array}{l}.0792 \\
(0.00)\end{array}$ & $\begin{array}{l}.0680 \\
(0.00)\end{array}$ \\
\hline N. CEOs & $\begin{array}{l}.4566 \\
(0.00)\end{array}$ & $\begin{array}{l}.4997 \\
(0.00)\end{array}$ & $\begin{array}{l}.3347 \\
(0.00)\end{array}$ & $\begin{array}{l}.4725 \\
(0.00)\end{array}$ & $\begin{array}{l}.5310 \\
(0.00)\end{array}$ & $\begin{array}{l}.3430 \\
(0.00)\end{array}$ \\
\hline N. DIRECTORSHIPS & $\begin{array}{l}.0067 \\
(0.89)\end{array}$ & $\begin{array}{l}.0127 \\
(0.85)\end{array}$ & $\begin{array}{l}-.0065 \\
(0.86)\end{array}$ & $\begin{array}{l}.0079 \\
(0.88)\end{array}$ & $\begin{array}{l}-.0085 \\
(0.89)\end{array}$ & $\begin{array}{l}-.0155 \\
(0.69)\end{array}$ \\
\hline STATE OWNERSHIP & $\begin{array}{l}.2573 \\
(0.77)\end{array}$ & $\begin{array}{l}.2554 \\
(0.48)\end{array}$ & $\begin{array}{l}-.0074 \\
(0.97)\end{array}$ & $\begin{array}{l}.2453 \\
(0.47)\end{array}$ & $\begin{array}{l}.1017 \\
(0.66)\end{array}$ & $\begin{array}{r}-.0174 \\
(0.95)\end{array}$ \\
\hline LARGEST SHAREHOLDER & $\begin{array}{c}-.5573 \\
(0.20)\end{array}$ & $\begin{array}{r}-.8612 \\
(0.12)\end{array}$ & $\begin{array}{r}-.0849 \\
(0.81)\end{array}$ & $\begin{array}{l}-.6262 \\
(0.16)\end{array}$ & $\begin{array}{l}-.7326 \\
(0.13)\end{array}$ & $\begin{array}{l}-.1083 \\
(0.76)\end{array}$ \\
\hline SECOND SHAREHOLDER & $\begin{array}{c}-2.2552 \\
(0.03)\end{array}$ & $\begin{array}{c}-1.9916 \\
(0.08)\end{array}$ & $\begin{array}{l}-.5738 \\
(0.44)\end{array}$ & $\begin{array}{c}-2.3760 \\
(0.02)\end{array}$ & $\begin{array}{c}-2.1257 \\
(0.04)\end{array}$ & $\begin{array}{l}-.6495 \\
(0.36)\end{array}$ \\
\hline SYNDICATE & $\begin{array}{c}-.0285 \\
(0.89)\end{array}$ & $\begin{array}{l}.3438 \\
(0.37)\end{array}$ & $\begin{array}{l}-.0465 \\
(0.78)\end{array}$ & $\begin{array}{l}.0001 \\
(1.00)\end{array}$ & $\begin{array}{l}.5193 \\
(0.15)\end{array}$ & $\begin{array}{r}-.0757 \\
(0.61)\end{array}$ \\
\hline CEO OWNERSHIP & $\begin{array}{l}-.2400 \\
(0.01)\end{array}$ & $\begin{array}{c}-.2359 \\
(0.04)\end{array}$ & $\begin{array}{l}-.2282 \\
(0.01)\end{array}$ & $\begin{array}{l}-.2539 \\
(0.00)\end{array}$ & $\begin{array}{l}-.2321 \\
(0.02)\end{array}$ & $\begin{array}{l}-.2417 \\
(0.01)\end{array}$ \\
\hline SIZE & $\begin{array}{l}-.0413 \\
(0.51)\end{array}$ & $\begin{array}{l}.0247 \\
(0.77)\end{array}$ & $\begin{array}{l}.0290 \\
(0.65)\end{array}$ & $\begin{array}{l}-.0548 \\
(0.43)\end{array}$ & $\begin{array}{l}-.0099 \\
(0.89)\end{array}$ & $\begin{array}{l}-.0008 \\
(0.99)\end{array}$ \\
\hline $\begin{array}{l}\text { SALES Growth } \times \text { FAMILY } \\
\text { OWNERSHIP } \\
\text { SALES Gr. Squared }^{*} \times \\
\text { FAMILY OWNERSHIP }\end{array}$ & $\begin{array}{l}.1150 \\
(0.82) \\
.7395 \\
(0.45)\end{array}$ & & & & & \\
\hline $\begin{array}{l}\text { EBITDA Growth } \times \\
\text { FAMILY OWNERSHIP }\end{array}$ & & $\begin{array}{r}-.7186 \\
(0.06)\end{array}$ & & & & \\
\hline $\begin{array}{l}\text { EBITDA Gr. Squared* } \times \\
\text { FAMILY OWNERSHIP }\end{array}$ & & $\begin{array}{l}.5721 \\
(0.08)\end{array}$ & & & & \\
\hline $\begin{array}{l}\text { STOCK RETURN } \times \\
\text { FAMILY OWNERSHIP } \\
\text { STOCK RETURN Squared* } \\
\times \text { FAMILY OWNERSHIP }\end{array}$ & & & $\begin{array}{l}-.6801 \\
(0.08) \\
.3009 \\
(0.58)\end{array}$ & & & \\
\hline $\begin{array}{l}\text { SALES Growth } \times \text { SECOND } \\
\text { SHAREHOLDER }>9 \%\end{array}$ & & & & $\begin{array}{l}-.1271 \\
(0.87)\end{array}$ & & \\
\hline $\begin{array}{l}\text { SALES Gr. Squared* } \\
\text { SECOND SHAREHOLDER }>9 \%\end{array}$ & & & & $\begin{array}{l}.5392 \\
(0.79)\end{array}$ & & \\
\hline $\begin{array}{l}\text { EBITDA Growth } \times \\
\text { SECOND SHAREHOLDER >9\% }\end{array}$ & & & & & $\begin{array}{l}.3572 \\
(0.31)\end{array}$ & \\
\hline $\begin{array}{l}\text { EBITDA Gr. Squared }{ }^{*} \times \\
\text { SECOND SHAREHOLDER }>9 \%\end{array}$ & & & & & $\begin{array}{l}-.6210 \\
(0.06)\end{array}$ & \\
\hline $\begin{array}{l}\text { STOCK RETURN } \times \\
\text { SECOND SHAREHOLDER }>9 \% \\
\text { STOCK RETURN Squared } \times \\
\text { SECOND SHAREHOLDER }>9 \%\end{array}$ & & & & & & $\begin{array}{l}1.0135 \\
(0.05) \\
-2.0920 \\
(0.04)\end{array}$ \\
\hline Pseudo $\mathrm{R}^{2}$ & 0.32 & 0.34 & 0.30 & 0.32 & 0.35 & 0.30 \\
\hline $\mathrm{LR}^{* \star}$ & 0.000 & 0.003 & 0.365 & 0.013 & 0.002 & 0.004 \\
\hline $\mathrm{LR}^{* \star *}$ & 0.249 & 0.161 & 0.006 & 0.948 & 0.065 & 0.003 \\
\hline N. Observations & 231 & 193 & 268 & 231 & 193 & 268 \\
\hline \multicolumn{7}{|c|}{$\begin{array}{l}\text { Notes. Huber-White standard errors. P-values in parenthesis. }{ }^{*} \text { Defined as the product of the variable and its absolute } \\
\text { value. }{ }^{* *} \text { Likelihood ratio test of the hypothesis that the coefficients of the performance variable are jointly different } \\
\text { from zero. }{ }^{* *} \text { Likelihood ratio test of the hypothesis that the coefficients of the interactions of the performance variable } \\
\text { and its square with CONTROL CHANGE are jointly different from zero. Each regression includes both time and } \\
\text { individual firm dummies. }\end{array}$} \\
\hline
\end{tabular}


Table 12. Probit estimates of the probability of Turnover C. Additional Interactions. Marginal effects. Dependent variable: Turnover $\mathrm{C}$

\begin{tabular}{|c|c|c|c|}
\hline Independent Variables: & 1 & 2 & 3 \\
\hline SALES Growth & $\begin{array}{l}-.973 \\
(0.00)\end{array}$ & & \\
\hline SALES Gr. Squared* & $\begin{array}{l}.5329 \\
(0.01)\end{array}$ & & \\
\hline EBITDA Growth & & $\begin{array}{l}-.9021 \\
(0.00)\end{array}$ & \\
\hline EBITDA Gr. Squared* & & $\begin{array}{l}.4337 \\
(0.02)\end{array}$ & \\
\hline STOCK RETURN & & & $\begin{array}{l}-.1036 \\
(0.59)\end{array}$ \\
\hline STOCK RETURN Squared* & & & $\begin{array}{l}-.1925 \\
(0.40)\end{array}$ \\
\hline AGE & $\begin{array}{l}.0027 \\
(0.67)\end{array}$ & $\begin{array}{l}.0001 \\
(0.98)\end{array}$ & $\begin{array}{l}.0034 \\
(0.57)\end{array}$ \\
\hline TENURE & $\begin{array}{l}.0646 \\
(0.00)\end{array}$ & $\begin{array}{l}.0848 \\
(0.00)\end{array}$ & $\begin{array}{l}.0696 \\
(0.00)\end{array}$ \\
\hline N. CEOs & $\begin{array}{l}.4808 \\
(0.00)\end{array}$ & $\begin{array}{l}.4428 \\
(0.00)\end{array}$ & $\begin{array}{l}.3496 \\
(0.00)\end{array}$ \\
\hline N. DIRECTORSHIPS & $\begin{array}{l}.0071 \\
(0.89)\end{array}$ & $\begin{array}{l}.0013 \\
(0.98)\end{array}$ & $\begin{array}{l}-.0124 \\
(0.74)\end{array}$ \\
\hline STATE OWNERSHIP & $\begin{array}{l}.2453 \\
(0.47)\end{array}$ & $\begin{array}{l}.3476 \\
(0.31)\end{array}$ & $\begin{array}{l}-.0052 \\
(0.98)\end{array}$ \\
\hline LARGEST SHAREHOLDER & $\begin{array}{l}-.6384 \\
(0.15)\end{array}$ & $\begin{array}{l}-.6538 \\
(0.17)\end{array}$ & $\begin{array}{l}-.2105 \\
(0.56)\end{array}$ \\
\hline SECOND SHAREHOLDER & $\begin{array}{l}-2.4571 \\
(0.02)\end{array}$ & $\begin{array}{l}-1.1684 \\
(0.25)\end{array}$ & $\begin{array}{l}-.7898 \\
(0.27)\end{array}$ \\
\hline SYNDICATE & $\begin{array}{l}.0039 \\
(0.98)\end{array}$ & $\begin{array}{l}.2245 \\
(0.53)\end{array}$ & $\begin{array}{l}-.0709 \\
(0.64)\end{array}$ \\
\hline CEO OWNERSHIP & $\begin{array}{l}-.2599 \\
(0.00)\end{array}$ & $\begin{array}{l}-.2412 \\
(0.02)\end{array}$ & $\begin{array}{l}.2335 \\
(0.01)\end{array}$ \\
\hline SIZE & $\begin{array}{l}-.0523 \\
(0.98)\end{array}$ & $\begin{array}{l}.0173 \\
(0.82)\end{array}$ & $\begin{array}{l}.0027 \\
(0.97)\end{array}$ \\
\hline $\begin{array}{l}\text { SALES Growth } \times \text { STATE } \\
\text { OWNERSHIP }\end{array}$ & $\begin{array}{l}.1118 \\
(0.89)\end{array}$ & & \\
\hline $\begin{array}{l}\text { SALES Gr. Squared }{ }^{*} \times \\
\text { STATE OWNERSHIP }\end{array}$ & $\begin{array}{l}1.0989 \\
(0.53)\end{array}$ & & \\
\hline $\begin{array}{l}\text { EBITDA Growth } \times \text { STATE } \\
\text { OWNERSHIP }\end{array}$ & & $\begin{array}{l}.4369 \\
(0.31)\end{array}$ & \\
\hline $\begin{array}{l}\text { EBITDA Gr. Squared }{ }^{*} \times \\
\text { STATE OWNERSHIP }\end{array}$ & & $\begin{array}{l}.0368 \\
(0.93)\end{array}$ & \\
\hline $\begin{array}{l}\text { STOCK RETURN } \times \\
\text { STATE OWNERSHIP }\end{array}$ & & & $\begin{array}{l}-.5001 \\
(0.17)\end{array}$ \\
\hline $\begin{array}{l}\text { STOCK RETURN Squared* } \\
\text { STATE OWNERSHIP }\end{array}$ & & & $\begin{array}{l}1.1878 \\
(0.01)\end{array}$ \\
\hline Pseudo $\mathrm{R}^{2}$ & 0.32 & 0.35 & 0.31 \\
\hline $\begin{array}{l}\text { N. observations } \\
\text { LR ** }\end{array}$ & $\begin{array}{l}231 \\
0.001\end{array}$ & $\begin{array}{l}193 \\
0.000\end{array}$ & $\begin{array}{l}268 \\
0.018\end{array}$ \\
\hline $\mathrm{LR}^{* * *}$ & 0.158 & 0.045 & 0.008 \\
\hline
\end{tabular}

Note: see Table 11 


\section{Appendix}

Table A1a. Probit estimates of the probability of

Turnover B. Marginal effects. Dependent variable:

Turnover B

\begin{tabular}{|c|c|c|c|}
\hline Independent Variables: & 1 & 2 & 3 \\
\hline SALES Growth & $\begin{array}{l}-.3265 \\
(0.12)\end{array}$ & & \\
\hline SALES Gr. Squared* & $\begin{array}{l}.1638 \\
(0.42)\end{array}$ & & \\
\hline EBITDA Growth & & $\begin{array}{l}-.5703 \\
(0.00)\end{array}$ & \\
\hline EBITDA Gr. Squared* & & $\begin{array}{l}.3127 \\
(0.01)\end{array}$ & \\
\hline STOCK RETURN & & & $\begin{array}{l}-.3227 \\
(0.02)\end{array}$ \\
\hline STOCK RETURN Squared* & & & $\begin{array}{l}.1495 \\
(0.27)\end{array}$ \\
\hline AGE & $\begin{array}{l}.0099 \\
(0.22)\end{array}$ & $\begin{array}{l}.0119 \\
(0.18)\end{array}$ & $\begin{array}{l}.0061 \\
(0.37)\end{array}$ \\
\hline TENURE & $\begin{array}{l}.0253 \\
(0.20)\end{array}$ & $\begin{array}{l}.0037 \\
(0.87)\end{array}$ & $\begin{array}{l}.0252 \\
(0.16)\end{array}$ \\
\hline N. TOP EXECUTIVES & $\begin{array}{l}.1356 \\
(0.00)\end{array}$ & $\begin{array}{l}.1449 \\
(0.00)\end{array}$ & $\begin{array}{l}.1353 \\
(0.00)\end{array}$ \\
\hline N. DIRECTORSHIPS & $\begin{array}{l}.0386 \\
(0.36)\end{array}$ & $\begin{array}{l}.0666 \\
(0.13)\end{array}$ & $\begin{array}{l}.0303 \\
(0.37)\end{array}$ \\
\hline STATE OWNERSHIP & $\begin{array}{l}.2304 \\
(0.39)\end{array}$ & $\begin{array}{l}.3836 \\
(0.13)\end{array}$ & $\begin{array}{l}.2170 \\
(0.39)\end{array}$ \\
\hline LARGEST SHAREHOLDER & $\begin{array}{l}-.0924 \\
(0.83)\end{array}$ & $\begin{array}{l}-.2204 \\
(0.62)\end{array}$ & $\begin{array}{l}-.2121 \\
(0.57)\end{array}$ \\
\hline SECOND SHAREHOLDER & $\begin{array}{l}-.3217 \\
(0.64)\end{array}$ & $\begin{array}{l}-.2865 \\
(0.71)\end{array}$ & $\begin{array}{l}-.5397 \\
(0.38)\end{array}$ \\
\hline SYNDICATE & $\begin{array}{l}-.2196 \\
(0.17)\end{array}$ & $\begin{array}{l}.0399 \\
(0.84)\end{array}$ & $\begin{array}{l}-.2371 \\
(0.07)\end{array}$ \\
\hline CEO OWNERSHIP & $\begin{array}{l}-.2087 \\
(0.12)\end{array}$ & $\begin{array}{l}-.2239 \\
(0.12)\end{array}$ & $\begin{array}{l}-.1984 \\
(0.05)\end{array}$ \\
\hline SIZE & $\begin{array}{l}.0011 \\
(0.97)\end{array}$ & $\begin{array}{l}.0151 \\
(0.82)\end{array}$ & $\begin{array}{l}.0139 \\
(0.78)\end{array}$ \\
\hline $\begin{array}{l}\text { Pseudo } R^{2} \\
\text { LR }^{\star \star} \\
\text { N. observations }\end{array}$ & $\begin{array}{l}0.19 \\
0.213 \\
359\end{array}$ & $\begin{array}{l}0.23 \\
0.000 \\
329\end{array}$ & $\begin{array}{l}0.19 \\
0.024 \\
420\end{array}$ \\
\hline
\end{tabular}

Note: see Table 11

Table A1b. Changes in the probability of turnover B induced by

a percentage change in the performance measure: $\frac{\partial \Phi}{\partial \ln x}$.

\begin{tabular}{lccc}
\hline & 1 & 2 & 3 \\
\hline SALES Growth & -.021 & & \\
EBITDA Growth & & -.018 & \\
STOCK RETURN & & & -.015 \\
\hline
\end{tabular}


Table A2a. Probit estimates of the probability of Turnover A. Marginal effects. Dependent variable: Turnover A

\begin{tabular}{|c|c|c|c|}
\hline Independent Variables: & 1 & 2 & 3 \\
\hline SALES Growth & $\begin{array}{l}.2254 \\
(0.28)\end{array}$ & & \\
\hline SALES Gr. Squared* & $\begin{array}{r}-.2221 \\
(0.31)\end{array}$ & & \\
\hline EBITDA Growth & & $\begin{array}{r}-.1942 \\
(0.18)\end{array}$ & \\
\hline EBITDA Gr. Squared* & & $\begin{array}{l}.1228 \\
(0.31)\end{array}$ & \\
\hline STOCK RETURN & & & $\begin{array}{l}.0468 \\
(0.73)\end{array}$ \\
\hline STOCK RETURN Squared* & & & $\begin{array}{l}.0225 \\
(0.86)\end{array}$ \\
\hline AGE & $\begin{array}{c}-.0047 \\
(0.71)\end{array}$ & $\begin{array}{c}-.0082 \\
(0.51)\end{array}$ & $\begin{array}{r}-.0084 \\
(0.43)\end{array}$ \\
\hline TENURE & $\begin{array}{l}.0175 \\
(0.55)\end{array}$ & $\begin{array}{l}.0109 \\
(0.72)\end{array}$ & $\begin{array}{l}.0098 \\
(0.85)\end{array}$ \\
\hline BOARD SIZE & $\begin{array}{l}.0478 \\
(0.01)\end{array}$ & $\begin{array}{l}.0514 \\
(0.00)\end{array}$ & $\begin{array}{l}.0622 \\
(0.00)\end{array}$ \\
\hline N. DIRECTORSHIPS & $\begin{array}{l}.0144 \\
(0.82)\end{array}$ & $\begin{array}{l}.0332 \\
(0.62)\end{array}$ & $\begin{array}{l}.0098 \\
(0.85)\end{array}$ \\
\hline STATE OWNERSHIP & $\begin{array}{l}.2463 \\
(0.39)\end{array}$ & $\begin{array}{l}-.1306 \\
(0.68)\end{array}$ & $\begin{array}{c}-.2429 \\
(0.35)\end{array}$ \\
\hline LARGEST SHAREHOLDER & $\begin{array}{r}-.9422 \\
(0.07)\end{array}$ & $\begin{array}{c}-1.2019 \\
(0.03)\end{array}$ & $\begin{array}{r}-.6585 \\
(0.14)\end{array}$ \\
\hline SECOND SHAREHOLDER & $\begin{array}{c}-1.4254 \\
(0.02)\end{array}$ & $\begin{array}{c}-1.4210 \\
(0.05)\end{array}$ & $\begin{array}{r}-.6970 \\
(0.23)\end{array}$ \\
\hline SYNDICATE & $\begin{array}{c}-.0619 \\
(0.72)\end{array}$ & $\begin{array}{l}.3217 \\
(0.06)\end{array}$ & $\begin{array}{r}-.0281 \\
(0.86)\end{array}$ \\
\hline CEO OWNERSHIP & $\begin{array}{r}-.1572 \\
(0.33)\end{array}$ & $\begin{array}{c}-.1313 \\
(0.45)\end{array}$ & $\begin{array}{c}-.1896 \\
(0.14)\end{array}$ \\
\hline SIZE & $\begin{array}{l}.0153 \\
(0.81)\end{array}$ & $\begin{array}{l}.0765 \\
(0.22)\end{array}$ & $\begin{array}{l}.0675 \\
(0.20)\end{array}$ \\
\hline $\begin{array}{l}\text { Pseudo } R^{2} \\
\text { LR }^{\star \star} \\
\text { N. observations }\end{array}$ & $\begin{array}{c}0.19 \\
0.544 \\
459 \\
\end{array}$ & $\begin{array}{c}0.20 \\
0.433 \\
434 \\
\end{array}$ & $\begin{array}{c}0.20 \\
0.627 \\
544 \\
\end{array}$ \\
\hline
\end{tabular}




\section{References}

Banca d'Italia (1998) Relazione Annuale, Roma.

Barca, F. (1994) Imprese in Cerca di Padrone. Proprietà e Controllo nel Capitalismo Italiano, Bari.

Barca, F. (1996) "On Corporate Governance in Italy: Issues, Facts and Agenda". Fondazione E.N.I. Enrico Mattei, Working Paper N.10-96.

Barca, F. and S. Trento (1997) "State Ownership and the Evolution of Italian Corporate Governance" Industrial and Corporate Change, 6, 533-559.

Bianco, M. and P. Casavola (1999) "Italian Corporate Governance: Effect on Financial Structure and Firm Performance" European Economic Review, 43, 1057-1069.

Bianco, M., C. Gola, and L. F. Signorini (1996) "Dealing with Separation Between Ownership and Control: State, Family, Coalitions and Pyramidal Groups in Italian Corporate Governance" Fondazione Mattei Working Paper N. 5.96.

Bianco, M. and E. Pagnoni (1997) "Interlocking Directorates Across Listed Companies in Italy: the Case of Banks" Banca Nazionale del Lavoro Quarterly Review, Special Issue on Property, Control and Corporate Governance of Banks, March.

Bolton, P. and E-L. Von Thadden (1998) "Blocks, Liquidity, and Corporate Control" Journal of Finance, 53, 1-25.

Brioschi, F. et al. (1990) Gruppi di Imprese e Mercato Finanziario, Nuova Italia Scientifica, Roma.

Brunello, G., C. Graziano, and B. Parigi (1999) "Executive Compensation and Firm Performance in Italy" International Journal of Industrial Organization, forthcoming.

Burkart, M., D. Gromb, F. Panunzi (1997) "Large Shareholders, Monitoring, and the Value of the Firm" Quarterly Journal of Economics 112, 693-728.

Calepino dell'Azionista (1987-1997), Mediobanca, Milan.

Caprio, L. et al. (1994) 'I Trasferimenti del Controllo di Società Quotate in Italia: Un' Analisi Empirica dei Prezzi e dei Risultati per gli Azionisti di Minoranza" Finanza Impresa e Mercati, 6, 355-393.

Coughlan, A.T. and R.M. Schmidt (1985) "Executive Compensation, Managerial Turnover, and Firm Performance: an Empirical Investigation" Journal of Accounting and Economics, 7, 43-66.

Crisci, G. and G. Tarizzo (1995) "Il Governo dell'Impresa: Il Ruolo dei C.d.A. nelle aziende Italiane" Le Società, 5, 607-616.

Denis, D. J. and D.K. Denis (1995) "Performance Changes Following Managerial 
Dismissals" Journal of Finance, 50, 1029-1058.

Denis, D. J. and A. Sarin (1999) "Ownership and Board Structures in Publicly Traded Corporations" Journal of Financial Economics, 52, 187-223.

Denis, D.J. et al. (1997) "Ownership Structure and Top Executive Turnover" Journal of Financial Economics, 45, 193-221.

Eisenberg, T., S. Sundgren and M.T. Wells (1998) "Larger Board Size and Decreasing Firm Value in Small Firms" Journal of Financial Economics, 48, 35-54.

Gispert, C. (1998) "Board Turnover and Firm Performance in Spanish Companies", Universitat Autònoma de Barcelona, Working Paper.

Greene, W. (1983) Econometric Analysis, McGraw-Hill, New York.

Hermalin, B. E. and M. S. Weisbach (1988) "Determinants of Board Composition" Rand Journal of Economics, 19, 95-112.

Kaplan, S. (1994a) "Top Executives Rewards and Firm Performance: A Comparison of Japan and the United States" Journal of Political Economy, 102, 510-546.

Kaplan, S. (1994b) "Top Executives, Turnover, and Firm Performance in Germany" Journal of Law Economics and Organization, 10, 142-159.

Kaplan, S. (1997) "Corporate Governance and Corporate Performance: A Comparison of Germany, Japan and the U.S." Journal of Applied Corporate Finance, 86-93.

Kaplan, S. and B. Minton (1994) "Appointments of Outsiders to Japanese Boards. Determinants and Implications for Managers" Journal of Financial Economics, 36, 225258.

Kang J. and A. Shivdasani (1995) "Firm Performance, Corporate Governance, and Top Executive Turnover in Japan" Journal of Financial Economics, 38, 29-58.

Khorana, A. (1996) "Top Management Turnover. An Empirical Investigation of Mutual Fund Managers" Journal of Financial Economics, 40, 403-427.

Kose, J. and L. W. Senbet (1998) "Corporate Governance and Board Effectiveness" Journal of Banking and Finance, 22, 371-401

La Porta, R., F. Lopez-de-Silanes, A. Shleifer, R. W. Vishny (1997) "Legal Determinants of External Finance" Journal of Finance, 52, 1131-1150.

La Porta, R., F. Lopez-de-Silanes, A. Shleifer, R. (1999) "Corporate Ownership Around the World" Journal of Finance, 54, 471-517.

Lausten, M. (1998) "CEO Turnover, Firm Performance and Corporate Governance", Aarhus School of Business Working Paper.

Mayer, C. (1998) "Financial Systems and Corporate Governance: A Review of the 
International Evidence" Journal of Institutional and Theoretical Economics, 154, 144-165.

Morck, R., A. Shleifer and R. Vishny (1988) "Management Ownership and Market Valuation" Journal of Financial Economics, 20, 293-315.

Murphy K. and J. Zimmerman (1993) "Financial Performance Surrounding C.E.O. Turnover" Journal of Accounting and Economics, 16, 273-315.

Nicodano, G. (1998) "Corporate Groups, Dual-Class Shares and the Value of Voting Rights" Journal of Banking and Finance, 22, 1117-1137.

Pagano, M. and A. Röell (1998) "The Choice of Stock Ownership Structure: Agency Costs, Monitoring, and the Decision to Go Public" Quarterly Journal of Economics, 187-225.

Renneboog, L. (1996) "Ownership, Managerial Control and the Governance of Companies Listed on the Brussels Stock Exchange" Journal of Banking and Finance forthcoming.

Rosenstein, S. and J. Wyatt (1997) "Inside Directors, Board Effectiveness, and Shareholder Wealth" Journal of Financial Economics, 44, 229-250.

R\&S (1994) Mediobanca, Milan.

Shleifer, A. and R. Vishny (1996) "A Survey of Corporate Governance". N.B.E.R. Working Paper N. 5554, April.

Sole 24 Ore (II) (1987-1998), Rome.

Taccuino dell'Azionista (1987-1997), Edizioni Sole 24 Ore, Milan.

Warner, J., R. Watts and K. Wruck (1988) "Stock Prices and Management Changes" Journal of Financial Economics, 20, 461-492.

Weisbach, M. (1988) "Outside Directors and C.E.O. Turnover" Journal of Financial Economics, 20, 431-460.

Yermack, D. (1996) "Higher Market Valuation of Companies with a Small Board of Directors" Journal of Financial Economics, 40, 185-211.

Zingales, L. (1994) "The Value of the Voting Right: A Study of the Milan Stock Exchange Experience" Review of Financial Studies, 7, 125-148. 